Article

\title{
Assessing Soil-like Materials for Ecosystem Services Provided by Constructed Technosols
}

\author{
Kristina Ivashchenko ${ }^{1,2, *}$, Emanuela Lepore ${ }^{2,3}$, Viacheslav Vasenev ${ }^{2,4} \oplus^{\circ}$, Nadezhda Ananyeva ${ }^{1}$, Sofiya Demina ${ }^{2}$, \\ Fluza Khabibullina ${ }^{2}$, Inna Vaseneva ${ }^{2}$, Alexandra Selezneva ${ }^{1}$, Andrey Dolgikh ${ }^{2,5}{ }^{\circledR}$, Sofia Sushko ${ }^{1,2,6}$, \\ Sara Marinari ${ }^{3}{ }^{-1}$ and Elvira Dovletyarova ${ }^{2}$
}

1 Institute of Physicochemical and Biological Problems in Soil Science, Russian Academy of Sciences, 142290 Pushchino, Russia; ananyeva@rambler.ru (N.A.); alexandra_seleznyova@mail.ru (A.S.); sushko-sv@rudn.ru (S.S.)

2 Department of Landscape Design and Sustainable Ecosystems, Agrarian-Technological Institute, Peoples' Friendship University of Russia, 117198 Moscow, Russia; Emanuela.lepore@studenti.unitus.it (E.L.); vasenyov@mail.ru (V.V.); ibatulina_sa@pfur.ru (S.D.); khabibullina.fluza@mail.ru (F.K.); vaseneva-iz@rudn.ru (I.V.); dolgikh@igras.ru (A.D.); dovletyarova-ea@rudn.ru (E.D.)

3 Department for Innovation in Biological, Agro-Food and Forest Systems DIBAF, University of Tuscia, 01100 Viterbo, Italy; marinari@unitus.it

4 Soil Geography and Landscape Group, Wageningen University, 6700 Wageningen, The Netherlands

5 Institute of Geography, Russian Academy of Sciences, 119017 Moscow, Russia

6 Agrophysical Research Institute, 195220 Saint-Petersburg, Russia

* Correspondence: ivashchenko-kv@rudn.ru

check for

updates

Citation: Ivashchenko, K.; Lepore, E.; Vasenev, V.; Ananyeva, N.; Demina,

S.; Khabibullina, F.; Vaseneva, I.;

Selezneva, A.; Dolgikh, A.; Sushko, S.; et al. Assessing Soil-like Materials for Ecosystem Services Provided by Constructed Technosols. Land 2021, 10, 1185. https://doi.org/10.3390/ land10111185

Academic Editor: Cezary Kabala

Received: 26 September 2021

Accepted: 30 October 2021

Published: 4 November 2021

Publisher's Note: MDPI stays neutral with regard to jurisdictional claims in published maps and institutional affiliations.

Copyright: (c) 2021 by the authors. Licensee MDPI, Basel, Switzerland. This article is an open access article distributed under the terms and conditions of the Creative Commons Attribution (CC BY) license (https:// creativecommons.org/licenses/by/ $4.0 /)$.

\begin{abstract}
Urbanization results to a wide spread of Technosols. Various materials are used for Technosols' construction with a limited attention to their ecosystem services or disservices. The research focuses on the integral assessment of soil-like materials used for Technosols' construction in Moscow megalopolis from the ecosystem services' perspective. Four groups of materials (valley peats, sediments, cultural layers, and commercial manufactured soil mixtures) were assessed based on the indicators, which are integral, informative, and cost-effective. Microbial respiration, C-availability, specific respiration, community level physiological profile, and Shannon' diversity index in the materials were compared to the natural reference to assess and rank the ecosystem services and disservices. The assessment showed that sediments and low-peat mixtures $(\leq 30 \%$ of peat in total volume) had a considerably higher capacity to provide C-sequestration, climate regulation and functional diversity services compared to peats and high-peat mixtures. Urban cultural layers provided ecosystem disservices due to pollution by potentially toxic elements and health risks from the pathogenic fungi. Mixtures comprising from the sediments with minor $(\leq 30 \%)$ peat addition would have a high potential to increase $\mathrm{C}$-sequestration and to enrich microbial functional diversity. Their implementation in urban landscaping will reduce management costs and increase sustainability of urban soils and ecosystem.
\end{abstract}

Keywords: urban soil; organo-mineral materials; ecosystem disservices; MicroResp technique; functional microbial diversity; fungi; Moscow megalopolis

\section{Introduction}

Urban ecosystems are to a great extent artificial by genesis and human-driven regarding their functions and services, and therefore highly variable and dynamic [1-3]. Considering the degree of anthropogenic impact, urban soils are identified as man-influenced, man-changed, or man-made [4]. From a variety of urban soils, soil constructions (constructed Technosols) are likely the most attractive and challenging for environmental assessment and modeling. Annually, thousands of tons of organic and mineral materials are imported into a big city and utilized for Technosols' construction [5-7]. The technologies and materials used for Technosols' construction are selected considering the 
management purposes, e.g., for reclamation, landscaping, establishment, and maintenance of urban green infrastructures [8-11]. A literature survey shows high diversity of materials used in urban soil engineering, including technic (e.g., rubble, sludge, wastes, and industrial by-products) and natural (e.g., peat, relocated topsoil, biosolids, and dredged (bottom) sediments) materials [9,12-15]. Various commercially manufactured materials are available on the market for landscaping and greening purposes. A variety of materials results in a unique diversity of chemical, physical, and biological properties of the constructed Technosols.

The quality of materials is usually legally regulated by state or municipal standards, which differ between countries and cities. For example, the mixture of agricultural topsoil, silt, clay, and sand is applied for greening public areas in Parma, Italy [16]. A mixture of compost, peat, and sand is recommended for planting trees at the roadsides in Rome [17]. In France, topsoil removed from agricultural and forest lands remains a key material for urban greening [15], whereas reusing the industrial by-products, wastes, and fine sediments is suggested as an environmentally friendly alternative [12,18]. In the United States, particularly in Chicago, biosolids and dredged sediments are implemented for renovation and greening works $[9,14]$. In Moscow, Russia, there are at least 50 companies, supplying about a hundred of different materials for greening, mainly comprised of peat, sand, compost, and excavated topsoil in different proportions $[5,8]$.

Although the quality standards of materials for the Technosols' construction differ between the cities, most of them are focused on several chemical properties (e.g., $\mathrm{pH}$ or content of potentially toxic elements, PTE), whereas their capacity to provide the ecosystem services remains overlooked $[19,20]$. Soil microorganisms are responsible for such important ecosystem's service as nutrients' cycles [21], pollutants' biodegradation [22-24] and climate regulation [25]. The provisioning of these services can be projected based on the microbial functional indicators, e.g., specific microbial respiration, community-level physiological profile, abundance of metabolic genes or enzymatic activity [26-29]. Microbial diversity contributes to ecosystem resistance to external stress; however, the presence of pathogenic species evokes substantial health risks and shall be considered as an eco-system disservice [30,31].

The research aimed to analyze soil-like materials used for Technosols' construction in Moscow megalopolis (Russia) and assess their quality based on chemical and microbial properties. The study outcomes shall allow re-thinking the existing soil quality standards and regulations from the ecosystem services' perspective to support urban sustainable development.

\section{Materials and Methods}

\subsection{Materials Used for Technosols' Construction in Moscow}

Moscow megalopolis extents over $2500 \mathrm{~km}^{2}$ and with the population above 12 million people is the largest city in Europe. Moscow is located in the Central part of East-European plain $\left(56^{\circ} \mathrm{N} ; 37^{\circ} \mathrm{E}\right)$ and has a temperate continental climate. Taiga and mixed forests on the Retisols dominating the natural areas of the region, in Moscow city, are to a great extent substituted by ornamental plants and green lawns on man-changed or man-made soils with a considerable portion of constructed Technosols [32,33]. More than 1 million $\mathrm{m}^{3}$ of soil-like materials (e.g., organic and mineral components and commercially manufactured mixtures) are annually imported into the city for the needs of civil engineering and green infrastructures' development $[5,8,34]$. A major part of the commercially manufactured mixtures available on the market composes from the similar components: valley peat, topsoil from meadow or arable lands, urban topsoil, and subsoil excavated before building construction, excavated river valley topsoil, compost, sand, dredged sediments, and sludge from water treatment stations. For this study, the most representative groups of the materials were purchased and collected: valley peats, sediments, urban cultural layers, and commercially manufactured mixtures (Table 1). 
Table 1. The origin, suppliers, and implementation of the studied materials for Technosols' construction (PTs, valley peat $(\mathrm{n}=4)$; SDs, sediments $(\mathrm{n}=2)$; CLs, cultural layers $(\mathrm{n}=4)$; $\mathrm{MIX}_{\mathrm{LPT}}$, mixture $(\mathrm{n}=3)$ with low peat content; $\mathrm{MIX}_{\mathrm{HPT}}$, mixture with high peat content $(n=3))$.

\begin{tabular}{cccc}
\hline Material & Origin & Suppliers & Implementation \\
\hline PTs & peatlands & peat mining companies & high \\
SDs & water body & water management companies & low \\
CLs & urban subsoil & producers of soil mixtures for gardening and landscaping & low \\
MIX & & high & high \\
MIX & man-made & & \\
\hline
\end{tabular}

The valley peats group included four samples from the major supplying companies. The sediments group was represented by sludge from surface water treatment stations (i.e., solid and non-soluble particles mechanically filtered prior the water supply) and bottom sediments (i.e., dredged sediments excavated from a lake bottom). Cultural layers included subsoil urban sediments accumulated during a long-term residential activity and frequently excavated during building and infrastructure constructing [35,36]. The commercially manufactured mixtures comprised from several components, including valley peat. Based on the portion of the valley peat in the mixtures' composition, they were subdivided to low-peat ( $\leq 30 \%$ of peat in total volume) and high-peat ( $\geq 75 \%$ of peat in total volume) (Table 2). All the materials are available on the market and were collected from the official suppliers-from two to four materials per group and three mixed samples (50 L bags) for each material. The topsoil $(0-10 \mathrm{~cm}$ ) of Retisols sampled in the four mixed forested parks of Moscow was considered as a natural soil reference.

Table 2. The composition of the investigated commercial mixtures.

\begin{tabular}{cccc}
\hline Mixture & Number & Composition & Volume Portion, $\%$ \\
\hline \multirow{3}{*}{ Low peat content } & I & peat/excavated urban topsoil/sand/excavated river valley topsoil & $30 / 30 / 30 / 10$ \\
& II & excavated urban topsoil/peat/compost/sand & $25 / 25 / 25 / 25$ \\
& III & excavated urban topsoil/valley peat/sand & $50 / 30 / 20$ \\
High peat content & IV & peat/sand & $75 / 25$ \\
& V & peat/compost/sand & $80 / 10 / 10$ \\
& VI & peat/sand & $95 / 5$ \\
\hline
\end{tabular}

\subsection{Integral Assessment of the Materials' Quality}

To assess the quality of the materials and project the ecosystem services they can provide, sub-samples ( $300 \mathrm{~g}$ ) were taken for each material and the natural soil reference. Sub-samples were sieved through a 2-mm mesh and subdivided into two parts. The first part was air-dried for chemical analysis. The second part was adjusted to $60 \%$ waterholding capacity and preincubated $\left(150 \mathrm{~g}, 22{ }^{\circ} \mathrm{C}, 7 \mathrm{~d}\right)$ in the thermostat in a plastic bag with air exchange. The preincubation stage eliminated initial variation in materials' temperature and moisture, and excluded possible $\mathrm{CO}_{2}$ efflux from the preparation procedures [37-39]. After preincubation, the sub-samples were analyzed for microbial properties.

\subsection{Chemical Analysis}

Total carbon $(\mathrm{C})$ and nitrogen $(\mathrm{N})$ contents were determined by spectrometry (CHNS932, LECO Corp, USA) after oxygen combustion $\left(1100{ }^{\circ} \mathrm{C}\right)$. The $\mathrm{pH}$ of peats, cultural layers, high-peat mixtures (the high organic material:water $=1: 10$ ) and soil, sediments, low-peat mixtures (material:water = 1:2.5) was measured by pH-meter (Basic Meter PB-11, Germany) [40]. Total contents of nickel $(\mathrm{Ni})$, zinc $(\mathrm{Zn})$, lead $(\mathrm{Pb})$, cadmium $(\mathrm{Cd})$ were measured by X-ray fluorescence spectroscopy (Spectroscan Max-GVM, Russia). 


\subsection{Microbiological Analysis}

In the subsamples, the microbial respiration (MR) was evaluated by $\mathrm{CO}_{2}$ production rate after its incubation for $24 \mathrm{~h}$ at the standardized condition at $22{ }^{\circ} \mathrm{C}[38,41]$. The measurement of $\mathrm{CO}_{2}$ was carried out by a gas chromatograph with a thermal conductivity detector (KrystaLLyuks 4000 M, Yoshkar-Ola, Russia). Microbial biomass carbon (MBC) was measured by substrate-induced respiration (SIR) method, which is based on the registration of the highest initial microbial $\mathrm{CO}_{2}$ production after glucose addition $[37,38]$. The subsamples ( $1.0 \mathrm{~g}$ each) were placed in a vial $(15 \mathrm{~mL}$ volume) and a glucose solution was added dropwise $\left(10 \mathrm{mg}\right.$ glucose $\mathrm{g}^{-1}$, volume was $\left.0.1 \mathrm{~mL}\right)$. The vial was tightly closed and incubated at $22{ }^{\circ} \mathrm{C}$ during $3.5 \mathrm{~h}$. The measured SIR was converted to MBC units $\left(\mu \mathrm{g} \mathrm{C} \mathrm{g}^{-1}\right)$ by the following equation: SIR $\left(\mu \mathrm{LCO}_{2} \mathrm{~g}^{-1} \mathrm{~h}^{-1}\right) \times 40.04+0.37$ [37]. The MBC:C and MR:MBC ratios were calculated to estimate microbial $C$-availability and specific respiration $\left(q \mathrm{CO}_{2}\right)$, respectively [25,42].

Community level physiological profile (CLPP) was measured by MicroResp ${ }^{\mathrm{TM}}$ technique $[27,28,43]$. Briefly, samples were put to the 96 -deep well $(945 \mu \mathrm{L}$ volume each) and solutions of four C-substrates' groups were added: amino acids (glycine, L-arginine, L-leucine, $\alpha$-aminobutyric, L-aspartic acids), carbohydrate (D-galactose, D-fructose, Dglucose), carboxylic acids (L-ascorbic, citric, oxalic acids), and phenolic acid (vanillic and syringic acids). The response of microbial community was detected by $\mathrm{CO}_{2}$ production by colorimetric method after $6 \mathrm{~h}$ of incubation with detection gel at $25^{\circ} \mathrm{C}$. The absorbance by the detection gel was analyzed at $595 \mathrm{~nm}$ wave length (microplate spectrophotometer FilterMax F5, USA) before and after incubation and expressed as $\mu \mathrm{g} \mathrm{C} \mathrm{g}^{-1} \mathrm{~h}^{-1}$ [28]. Microbial functional diversity was assessed through Shannon index: $\mathrm{H}^{\prime}=-\sum \mathrm{pi} \times \operatorname{lnpi}$ [44], where pi is the ratio of $\mathrm{CO}_{2}$ response on the addition of single $\mathrm{C}$-substrate to the sum of responses for all studied substrates.

The fungi species were cultivated on Getchinson's and Czapek's solid media, that allowed to cover the widely distributed fungi in materials consuming the cellulose and carbohydrates, respectively [45]. The Getchinson's solid medium consisted $2.5 \mathrm{~g} \mathrm{NaNO}_{3}$, $1.0 \mathrm{~g} \mathrm{~K}_{2} \mathrm{HPO}_{4}, 0.3 \mathrm{MgSO}_{4}, 0.1 \mathrm{~g} \mathrm{CaCl}_{2}, 0.1 \mathrm{NaCl}, 0.01 \mathrm{~g} \mathrm{FeCl}_{3}, 7.5 \mathrm{~g}$ agar L ${ }^{-1}$ water. The Czapek's medium included $30 \mathrm{~g}$ sucrose, $2.0 \mathrm{~g} \mathrm{NaNO}_{3}, 1.0 \mathrm{~g} \mathrm{~K}_{2} \mathrm{HPO}_{4}, 0.5 \mathrm{~g} \mathrm{MgSO}_{4}, 0.5 \mathrm{KCl}$, $0.01 \mathrm{~g} \mathrm{FeSO}_{4}, 15 \mathrm{~g}$ agar L $^{-1}$ water. Streptomycin sulfate $\left(100 \mathrm{mg} \mathrm{L}^{-1}\right)$ was added to the media for bacterial growth inhibition. Briefly, sterile water $(90 \mathrm{~mL})$ was added to each $10 \mathrm{~g}$ soil and each subsample materials' group, and shaken for $10 \mathrm{~min}$ [46]. Serial dilutions (from $10^{-2}$ to $10^{-9}$ ) were prepared by sequentially transferring $1 \mathrm{~mL}$ supernatant into glass tubes with $9 \mathrm{~mL}$ of sterile water. Subsamples $(0.1 \mathrm{~mL})$ at selected three dilutions were pipetted on the surface of three Petri dishes with each solid medium. The Getchinson's medium was covered by filter paper then. The dishes were incubated at $25^{\circ} \mathrm{C}$ during $10 \mathrm{~d}$ [47]. Fungi genus and species identification was based on their morphological characteristics using the manual [48]. The occurrence of the fungi was calculated as the ratio of the number of Petri dishes with an identified species to their total number for each subsample. Occurrence was measured as follows: $>83 \%$ is frequent, $33-83 \%$ is medium, and $<33 \%$ is rare. Pathogenic potential was identified according to the atlas of clinical fungi [49].

\subsection{Interpretation of Soil-like Materials' Properties from the Ecosystem Services' Perspective}

The ecosystem services' assessment was based on the studied microbial properties, which are often used as soil quality indicators $[26,50]$. The organic matter decomposition rate based on MR was used to assess the nutrients' cycle service. The higher value could indicate a better performance of the service, however, could also show the acceleration of $\mathrm{CO}_{2}$ production rate. Hence, the $q \mathrm{CO}_{2}$ value was considered to indicate the balance between $\mathrm{CO}_{2}$ production and $\mathrm{C}$ involved into microbial cells. The ratio of $\mathrm{MBC}$ to $\mathrm{C}$ determines $\mathrm{C}$-availability to microbes and together with $q \mathrm{CO}_{2}$ was used as indicators of the $\mathrm{C}$-sequestration and climate regulation service. The microbial response to specific organic acids (e.g., phenolic) was considered as the capacity to biodegradation of organic pollutants, which include a benzene ring. Shannon functional diversity index was considered to 
assess the functional biodiversity supporting service. All the selected indicators were standardized to the natural soil reference values, which potential to provide the ecosystem services was considered the highest. The disservices of the materials were assessed based on PTE content compared to the health threshold level and pathogens occurrence in comparison to the natural soil reference. The ecosystem services' performance was ranked from 0 to 1 (where 1 is the best performance). The ecosystem disservices' performance was ranked by the same scale, where 1 means the minimal disservices provided.

\subsection{Statistical Analysis}

All measurements were performed in three replicates and calculated for the dry weight of subsamples. One-way analysis of variance and subsequent multiple comparisons by Tukey's test were performed for comparing the chemical and microbial properties among the materials' groups. The comparison between the materials' groups and the natural soil reference was done based on Dunnett's test. The relationships between chemical and microbial properties were analyzed using Spearman's correlation. Redundancy analysis (RDA) was used to examine the relations of fungal community composition to $\mathrm{pH}$, nutrients $(\mathrm{C}, \mathrm{N})$, and PTE (Ni, Zn, Pb, Cd) contents among the studied materials. Data on fungi species occurrence were processed with Hellinger transformation [51]. Prior to RDA, a forward selection was performed to identify the best set of non-collinear explanatory variables with the highest adjusted multiple determination coefficient.

Significance level was accepted as 0.05. Statistical data analysis and visualization were processed in RStudio [52]. Data visualization was done by ggplot2 package [53]. Correlation matrix was visualized with the 'Performance Analytics' package. The RDA was performed using the 'vegan' package.

\section{Results}

\subsection{Chemical Properties}

The $\mathrm{pH}$ of all the materials was close to neutral with non-significant difference between the groups or with the natural soil reference (Table 3).

Table 3. Average $\mathrm{pH}$ and bulk of potentially toxic elements (PTE) $\left(\mathrm{mg} \mathrm{kg}^{-1}\right)$ in the soil-like materials (PTs, valley peat); SDs, sediments; CLs, cultural layers; $\mathrm{MIX}_{\mathrm{LPT}}$, mixture with low peat content; MIX $_{\mathrm{HPT}}$, mixture with high peat content).

\begin{tabular}{ccccccc}
\hline PRP & PTs $(\mathbf{n}=\mathbf{4})$ & $\begin{array}{c}\text { SDs } \\
(\mathbf{n}=\mathbf{2})\end{array}$ & CLs $(\mathbf{n}=\mathbf{4})$ & $\begin{array}{c}\text { MIX }_{\text {HPT }} \\
(\mathbf{n}=\mathbf{3})\end{array}$ & $\begin{array}{c}\text { MIX }_{\text {LPT }} \\
(\mathbf{n}=\mathbf{3})\end{array}$ & THL \\
\hline $\mathrm{pH}$ & $6.4 \pm 0.5 \mathrm{a}$ & $6.9 \pm 0.5 \mathrm{a}$ & $7.2 \pm 0.0 \mathrm{a}$ & $6.5 \pm 0.6 \mathrm{a}$ & $6.7 \pm 0.1 \mathrm{a}$ & $6.0-7.5$ \\
$\mathrm{Ni}$ & $23 \pm 6 \mathrm{a}$ & $23 \pm 5 \mathrm{a}$ & $12 \pm 1 \mathrm{~b}$ & $29 \pm 10 \mathrm{a}$ & $27 \pm 2 \mathrm{a}$ & 80 \\
$\mathrm{Zn}$ & $215 \pm 158 \mathrm{~b}$ & $140 \pm 12 \mathrm{~b}$ & $\mathbf{5 6 3} \pm \mathbf{2 1 2} \mathrm{a}$ & $54 \pm 14 \mathrm{c}$ & $53 \pm 3 \mathrm{c}$ & 220 \\
$\mathrm{~Pb}$ & $9 \pm 3 \mathrm{a}$ & $12 \pm 8 \mathrm{a}$ & $22 \pm 3 \mathrm{a}$ & $15 \pm 7 \mathrm{a}$ & $15 \pm 2 \mathrm{a}$ & 130 \\
$\mathrm{Cd}$ & $0.5 \pm 0.1 \mathrm{a}$ & $0.3 \pm 0.0 \mathrm{~b}$ & $0.6 \pm 0.0 \mathrm{a}$ & $0.5 \pm 0.1 \mathrm{a}$ & $0.2 \pm 0.0 \mathrm{~b}$ & 2.0 \\
\hline
\end{tabular}

PRP, properties. Values are reported as mean \pm standard error, different letters indicate a significant $(p<0.05)$ difference between the groups. Bold value represents the exceeding of threshold level (THL) for PTE (HS-514-11 regulation).

In contrast, $\mathrm{C}$ and $\mathrm{N}$ contents ranged more than one order of magnitude with the highest values in cultural layers and valley peats (Figure 1). Peat soil is widely recognized as the remarkable natural $\mathrm{C}$ stock, whereas high $\mathrm{C}$ and $\mathrm{N}$ content in cultural layers have an anthropogenic origin. They result from a long-term deposition during the residential activity and include organic wastes, wooden cheeps and other artifacts [35,54]. Only the low-peat mixtures contained a similar amount of $\mathrm{C}$ and $\mathrm{N}$ as a natural soil, whereas in all the other materials $C$ and $N$ contents exceeded the natural reference values 5 to 15 times. The C:N ratio for all the materials ranged between 10 and 20, indicating a balanced of $C$ and $\mathrm{N}$ input. Compared to the other materials, cultural layers had higher contents of $\mathrm{Cd}$ and $\mathrm{Zn}$, whereas $\mathrm{Pb}$ and $\mathrm{Ni}$ contents didn't differ significantly among the groups and were lower than the maximal permissible level recommended by Moscow' municipal regulations. 

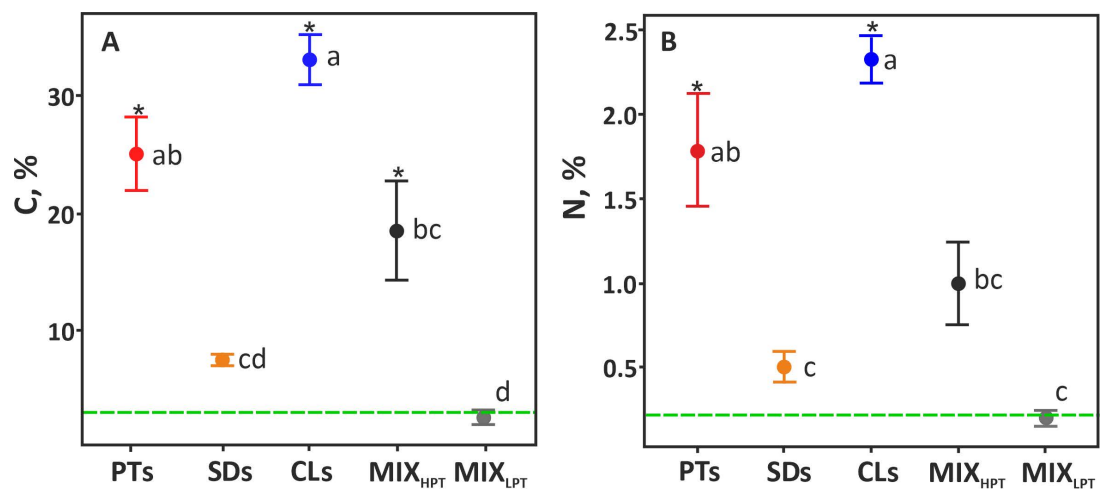

Figure 1. Mean (circles) and standard errors (bars) of total carbon (A) and nitrogen (B) in peats (PTs), sediments (SDs), cultural layers (CLs), high-peat (MIX $\mathrm{HPT}$ ) and low-peat (MIX $\mathrm{LPT}_{\mathrm{T}}$ ) mixtures. Dotted green line represents the mean for the natural soil reference. Letters indicate the significantly different groups (Tukey's test). Means with * indicate a significant difference from the natural soil (Dunnett's test).

\subsection{Microbial Properties}

An extremely high MR obtained for the cultural layers was two orders of magnitude above other materials and the natural soil reference (Figure 2A). The highest specific respiration was reported for the materials rich in easily mineralizable organic matter (peats, cultural layers and high-peat mixtures), whereas sediments and low-peat mixtures were not significantly different from the natural soil (Figure 2B). Assuming a balanced specific respiration in natural soils as (i.e., $q \mathrm{CO}_{2}$ ), sediments and low-peat mixtures were balanced as well, whereas the other substrates were not. The C-availability in the natural soils was significantly higher than in any soil-like material, and the lowest values were obtained for the peats and high-peat mixtures (Figure 2C). High $q \mathrm{CO}_{2}$ and low C-availability in peats and high-peat mixtures indicate their low capacity for $\mathrm{C}$ sequestration. Only the small part of $C$ stored in these materials could be consumed by microbes for anabolism and accumulated in microbial cells, whereas the major part was released as $\mathrm{CO}_{2}$.
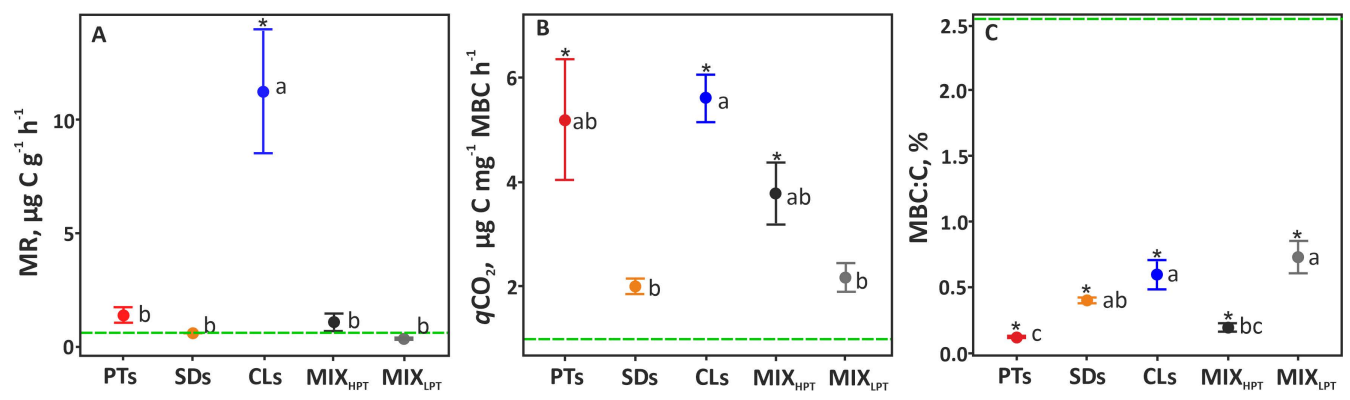

Figure 2. Microbial respiration (MR, A), microbial metabolic quotient $\left(q \mathrm{CO}_{2}, \mathbf{B}\right)$ and ratio of microbial biomass carbon to total carbon $(\mathrm{MBC}: \mathrm{C}, \mathrm{C})$ in soil-like materials. Dotted green line represents the mean for the natural soil reference. Letters indicate the significantly different groups (Tukey's test). Means with * indicate a significant difference from the natural soil (Dunnett's test).

The CLPP results showed that microbial structure in the peats was mostly shifted to groups consuming the ascorbic acid, whereas in the cultural layers and sediments, the highest response was obtained on the citric and ascorbic acids (Figure 3A). The response of microbial community on the arginine addition was found only for the peats and high-peat mixtures. For all materials except cultural layers, the capacity of microbial community to decompose complex organic compounds with benzene ring such as phenolic acids (vanillic and syringic) was lower compared to the natural soil. The highest microbial diversity was also reported for the natural soils, for which the Shannon index was considerably higher than in any of the soil-like materials. Among the materials, the index increased in a row: high-peat mixtures, sediments, peats, cultural layers, low-peat mixtures (Figure 3B). 

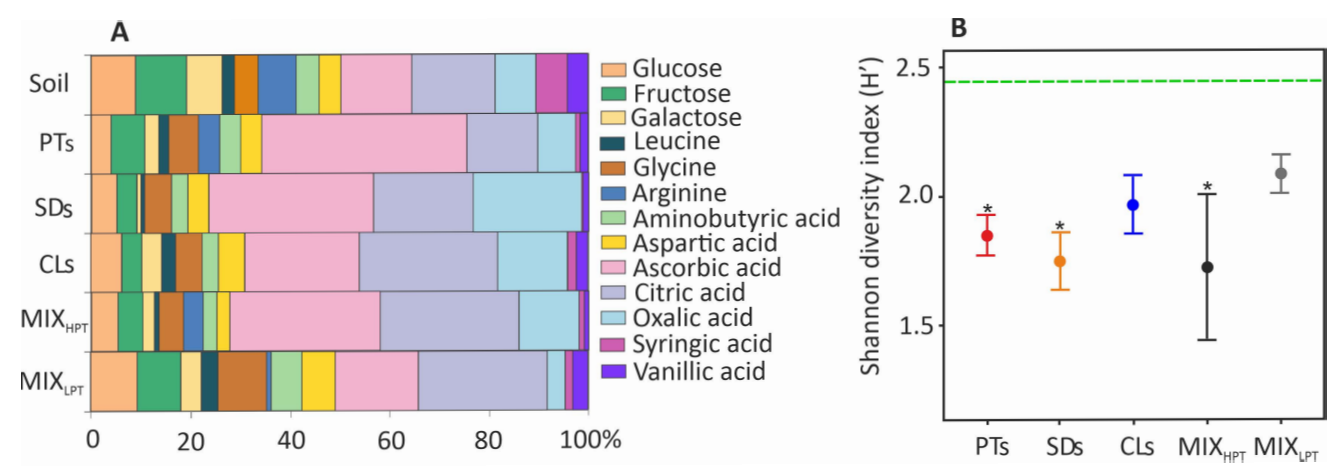

Figure 3. Community level physiological profile (A) expressed by contribution of respiration on addition of individual substrates to total substrate-induced respiration in the natural soil and soil-like materials. The Shannon diversity index (B) presents as mean (circles) are standard error (bars) for materials, dotted line represents the mean for the soil. Means with * indicate significantly differences from the natural soil (Dunnett's test).

A more detailed analysis of the fungal diversity in the materials allowed identifying 31 species from 16 genera (Table 4). Between 8 and 11 fungi species were identified in soil, peats, and mixtures, which was 1.6-4.0 times more than in the sediments and cultural layers. The identified species differed between the natural soil and soil-like materials, as well as among the materials' groups. The highest frequency of the opportunistic fungi genera (e.g., Aspergillus, Chaetomium and Geomyces) and plant pathogenic fungi genera (e.g., Verticillium genus) were found in cultural layers. These species could cause mycoses in individuals having a weakened immunity. They are also harmful for the plant leaves and stems. Considering the potential risks for human and plant health, the implementation of cultural layers for urban greening purposes is questionable. Some opportunistic fungi genera were also found in low-peat mixtures and in the natural soil reference; however, the frequency of occurrence was less compared to the cultural layers.

\subsection{Relationships between Microbial and Chemical Properties}

The difference in microbial properties between the investigated materials was partly driven by $\mathrm{C}$ and $\mathrm{N}$ contents and the polluting level by $\mathrm{Cd}$ and $\mathrm{Zn}$ (Figure 4). A positive significant strong correlation was shown between $\mathrm{MR}, \mathrm{C}, \mathrm{N}, \mathrm{Zn}$, and Cd contents, whereas a significant negative effect of contaminants on microbial properties was not shown.

The negative effects of the PTE on the microbial community (reflected in high MR) were reported for urban soils before $[54,55]$ and indicated stressful conditions for microbiome; however, the opposite effect of $\mathrm{C}$ and $\mathrm{N}$ input was expected. Apparently, $\mathrm{C}$ and $\mathrm{N}$ contents in some materials (e.g., in valley peats and high-peat mixtures) were so high that they could not be taken due to the exceeded capacity of their assimilation by microbial community, and therefore resulted in a $q \mathrm{CO}_{2}$ increase. The most optimal microbial functional capacity (low $q \mathrm{CO}_{2}$ ) was found at a range of 1.6 to $8.0 \%$ for $\mathrm{C}$ and 0.1 to $0.6 \%$ for $\mathrm{N}$ (Figure 5A,B).

Based on the RDA ordination of fungi species in the studied materials (Figure 6), the forward selection indicated that the best fitted model included $\mathrm{Pb}$ and $\mathrm{Ni}$ as factors, which explained $51.3 \%$ of the variance in fungal composition. Among these factors, $\mathrm{Pb}$ content was significant, explained $30.2 \%$ of variance, and was considered as gradient for RDA1 (pseudo $\mathrm{F}=1.7, p=0.006 ; 999$ permutations). The ordination showed that fungi of cultural layers were more exclusive and less diverse compared to the other studied materials. The occurrence of Verticillium and Aspergillus niger pathogens increased along the $\mathrm{Pb}$ contamination gradient and associated with cultural layers. 
Table 4. The occurrence of the fungi in the natural soil and soil-like materials and the potential health risks from the pathogenic fungi. Bold font represents the opportunistic fungi according to risk groups 1, which indicates the dangerous of fungi's impact on immunocompromised people (de Hoog et al., 2019).

\begin{tabular}{|c|c|c|c|c|c|c|c|c|}
\hline Fungi & Abbreviation & Health Risks & Soil & PTs & CLs & SDs & MIX $_{\mathrm{HPT}}$ & MIX $_{\text {LPT }}$ \\
\hline Acremonium strictum Gams & Astr & $\begin{array}{l}\text { pulmonary, pleuritis, } \\
\text { fungemia }\end{array}$ & - & - & - & - & - & ++ \\
\hline Aspergillus niger Tiegh. & Anig & $\begin{array}{c}\text { otomycosis, } \\
\text { aspergillosis }\end{array}$ & - & - & ++ & - & - & + \\
\hline Aspergillus sp. & Asper & & - & + & - & - & - & - \\
\hline Acremonium charticola Lindau & Achar & & - & - & - & - & - & ++ \\
\hline Chaetomium globosum Kunze & Cglob & $\begin{array}{l}\text { onychomycosis, } \\
\text { cutaneous lesions }\end{array}$ & - & + & - & + & - & - \\
\hline Chaetomium indicum Corda & Cind & & - & + & - & - & - & - \\
\hline Chaetomium spiralliforum Bainier & Cspi & & - & - & - & + & - & - \\
\hline Chaetomium spirale Zopf & Cspir & & - & - & - & + & - & - \\
\hline Chaetomium sp. & Csp & & ++ & + & - & + & & \\
\hline Geomyces pannorum Link & Gpan & onychomycosis & ++ & - & - & - & - & - \\
\hline $\begin{array}{l}\text { Gliocladium catenulatum } \\
\text { Gilman \& Abbott }\end{array}$ & Gcat & & - & - & - & + & - & - \\
\hline Gliocladium roseum Bainier & Gros & & - & - & +++ & - & - & - \\
\hline Monocillium $\mathrm{sp}$ & Mon & & - & + & - & - & - & - \\
\hline Monocillium pygmaea Chalab. & Mpyg & & ++ & - & - & - & - & - \\
\hline Mortierella polycephala Coem. & Mpol & & + & - & - & - & - & - \\
\hline Mortierella sp. & Mor & & + & - & - & - & - & ++ \\
\hline Mucor sp. & Muc & & - & + & - & - & - & - \\
\hline Paecilomyces farinosus Holm & Pfar & & - & - & +++ & - & - & - \\
\hline Penicillium islandicum Sopp & Pisl & & - & - & - & - & + & - \\
\hline Penicillium steckii Zaleski & Pst & & - & - & - & - & + & - \\
\hline Penicillium sclerotiorum Beyma & Pscl & & - & - & - & - & - & ++ \\
\hline Penicillium rubrum Stoll & Prub & & - & - & - & - & ++ & - \\
\hline Penicillium terlikowskii Zaleski & Pter & & - & - & - & - & ++ & - \\
\hline Penicillium sp. & Pen & & - & + & - & - & - & ++ \\
\hline Stachybotrys parvispora Hughes & Spar & & - & - & - & - & + & - \\
\hline Stachybotrys lobulatus Berk. & Slob & & - & + & - & + & - & - \\
\hline Trichoderma sp. & Trich & & ++ & - & - & - & - & - \\
\hline Verticillium sp. & Vert & plant diseases & - & - & + & - & - & - \\
\hline Moniliaceae sp.1 & Mon1 & & +++ & +++ & - & + & + & - \\
\hline Moniliaceae sp.2 & Mon2 & & + & ++ & - & + & +++ & +++ \\
\hline Micelia sterilia dark-colored & Msdc & & - & ++ & - & - & - & + \\
\hline
\end{tabular}

Occurrence was measured as follows: +++ , frequent $(>83 \%) ;++$, medium $(33-83 \%) ;+$, rare $(<33 \%) ;-$, no.

\subsection{From Properties towards Ecosystem Services}

Chemical and microbial properties of the analyzed soil-like materials were integrated and interpreted to assess the ecosystem services or disservices, which they can provide. A high capacity to provide functional biodiversity and nutrient cycles' services was shown for all the materials. For the cultural layers, however, the biodiversity service was hampered by the health risk disservice induced by the occurrence of the pathogenic fungi. At the same time, only a few materials (sediments and low-peat mixtures) had the potential to provide $\mathrm{C}$-sequestration and climate regulation services. For all the other materials with very high contents of easily mineralizable organic matter, the risks of $\mathrm{CO}_{2}$ emissions were much higher than in the natural soils, considered as a reference for the ecosystem services' assessment. In result, the capacity of cultural layers, peats, and high-peat mixtures to provide the service was assessed $20 \%$ lower than for sediments and low-peat mixtures and $80 \%$ lower than for the natural soil. An opposite pattern was shown the pollutants biodegradation services, which was performed by peats and high-peat mixtures 20 to 30\% better than by the sediments with low $\mathrm{C}$ and $\mathrm{N}$ contents. For cultural layers, an optimal performance of the pollutants' biodegradation services coincided with the disservice evoked by PTE pollution; therefore, cultural layers can be considered quite an ambiguous material for Technosols' construction. Services' and disservices' assessment aggregated on Figure 7 clearly illustrate the multi-functionality of the materials. Likely, the preliminary idea of the target service to obtain (or disservice to avoid) shall be developed prior to selecting the particular material for Technosols' construction. 


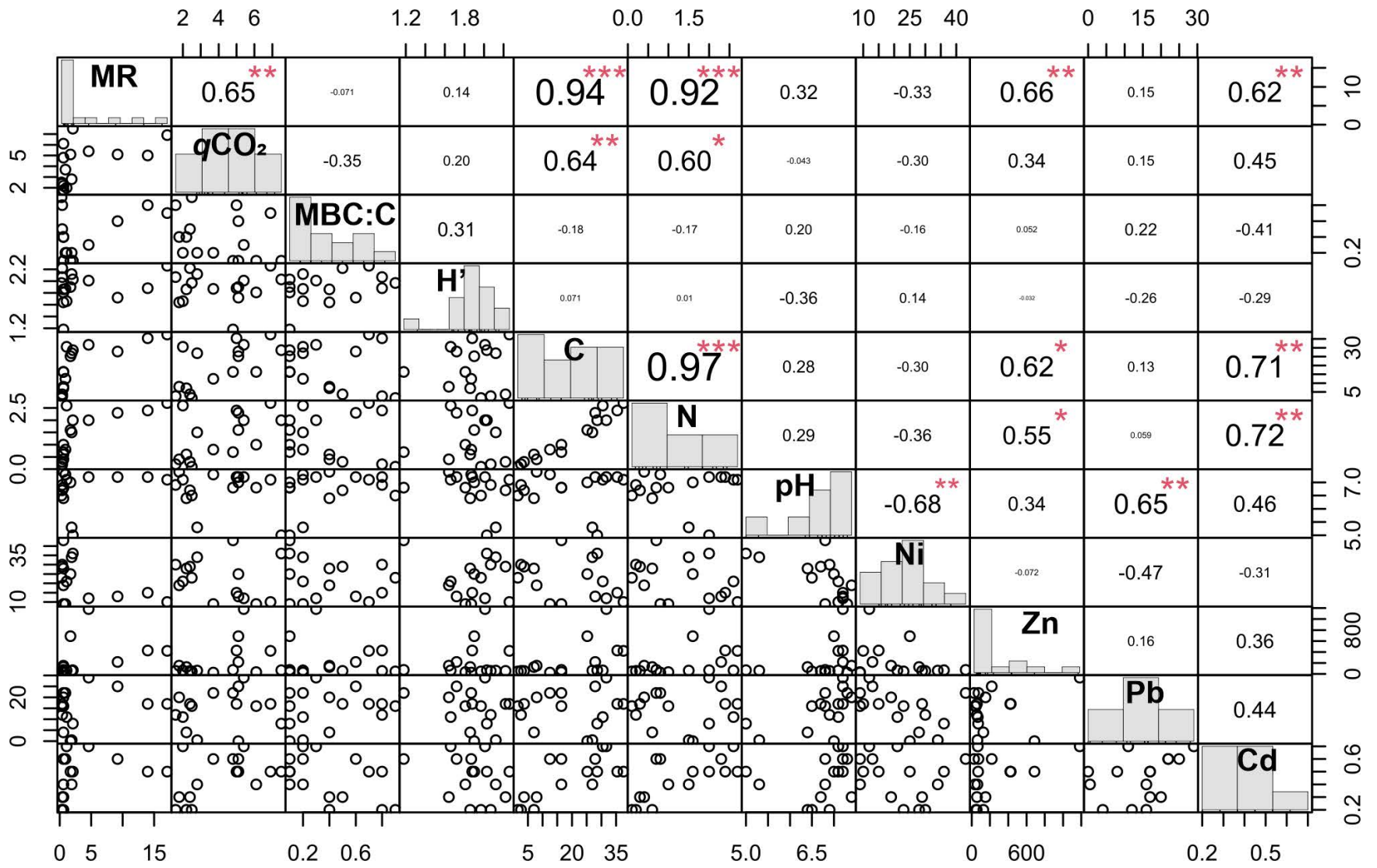

Figure 4. Relationships between microbial $\left(\mathrm{MR}, \mathrm{qCO}_{2}, \mathrm{MBC}: \mathrm{C}, \mathrm{H}^{\prime}\right)$ and chemical $(\mathrm{C}, \mathrm{N}, \mathrm{pH}, \mathrm{Ni}, \mathrm{Zn}, \mathrm{Pb}, \mathrm{Cd})$ properties of the soil-like materials $(\mathrm{n}=16)$. Significant correlation coefficients are indicated with ${ }^{*} \alpha \leq 0.05 ;{ }^{* *} 0.01 ;{ }^{* * *} 0.001$.
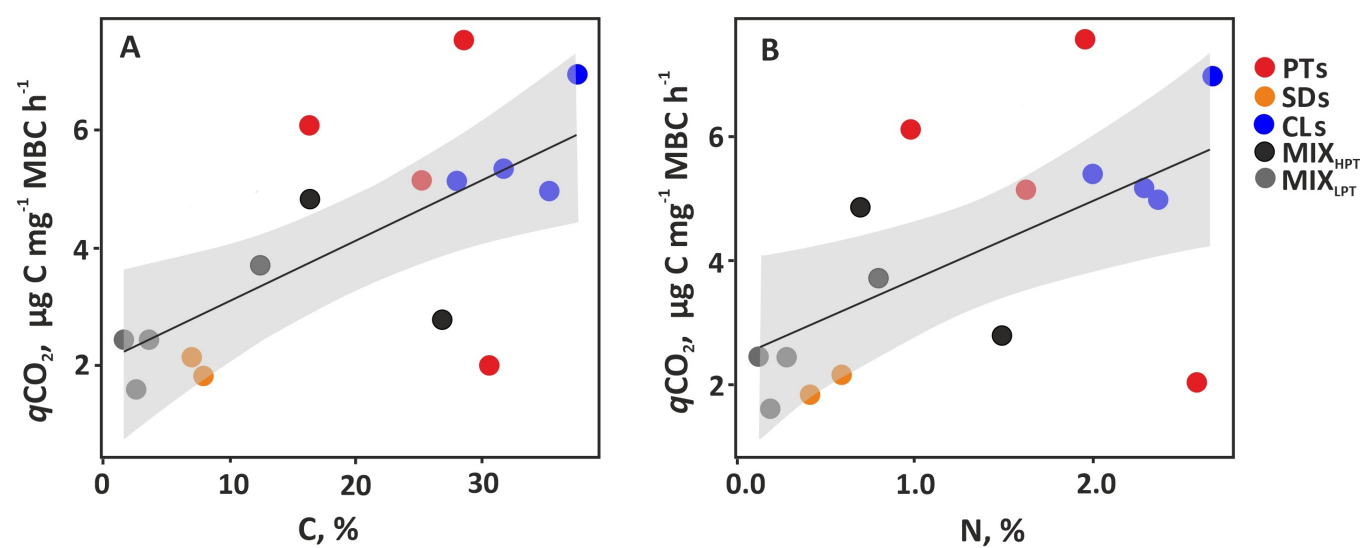

Figure 5. Scatter plot for microbial $\left(q \mathrm{CO}_{2}\right)$ and carbon $(\mathbf{A})$ and nitrogen $(\mathbf{B})$ of the soil-like materials. The gray 'bands' represent the standard error of the regression line. 


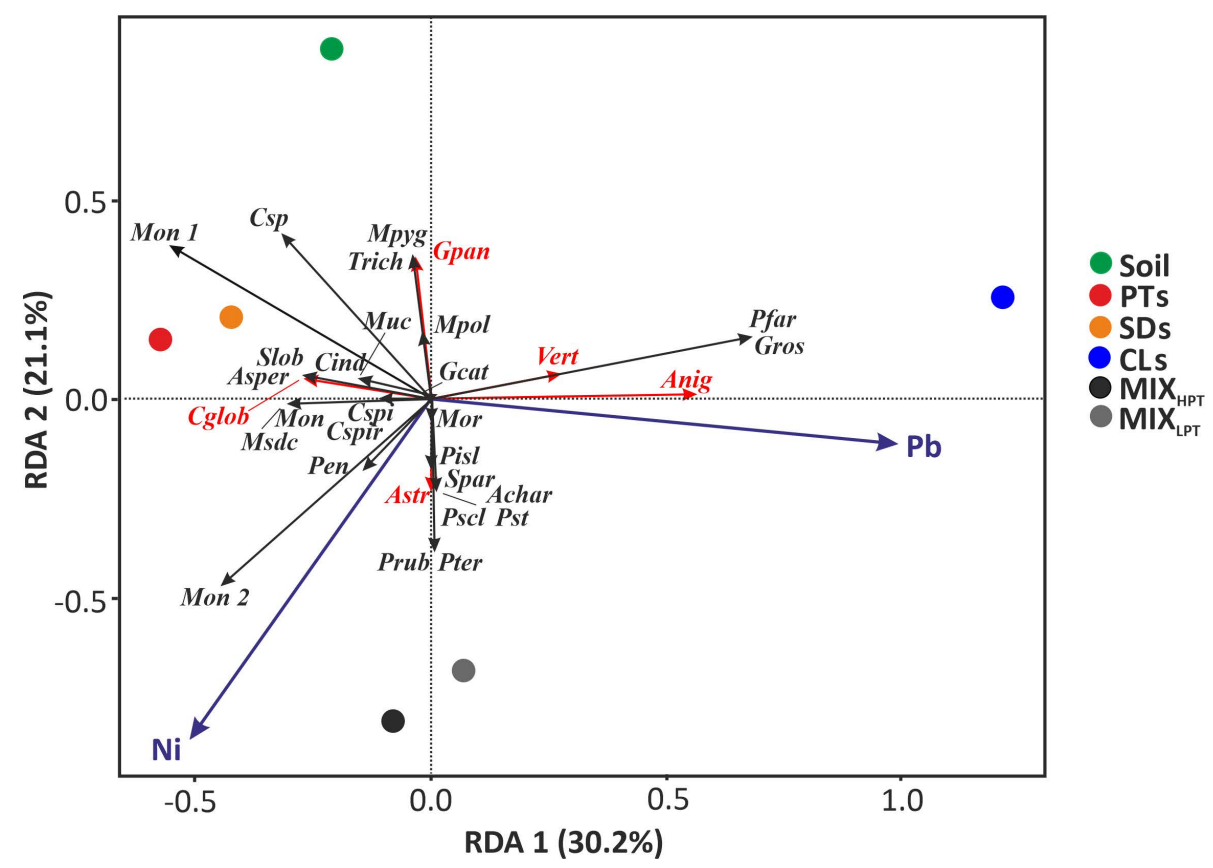

Figure 6. Ordination biplot of redundancy analysis for the fungi composition explained by $\mathrm{Pb}$ and $\mathrm{Ni}$ contents for the natural soil and soil-like materials. Non-pathogenic and pathogenic fungi are plotted as black and red arrows, respectively (fungi species abbreviations see in the Table 4).

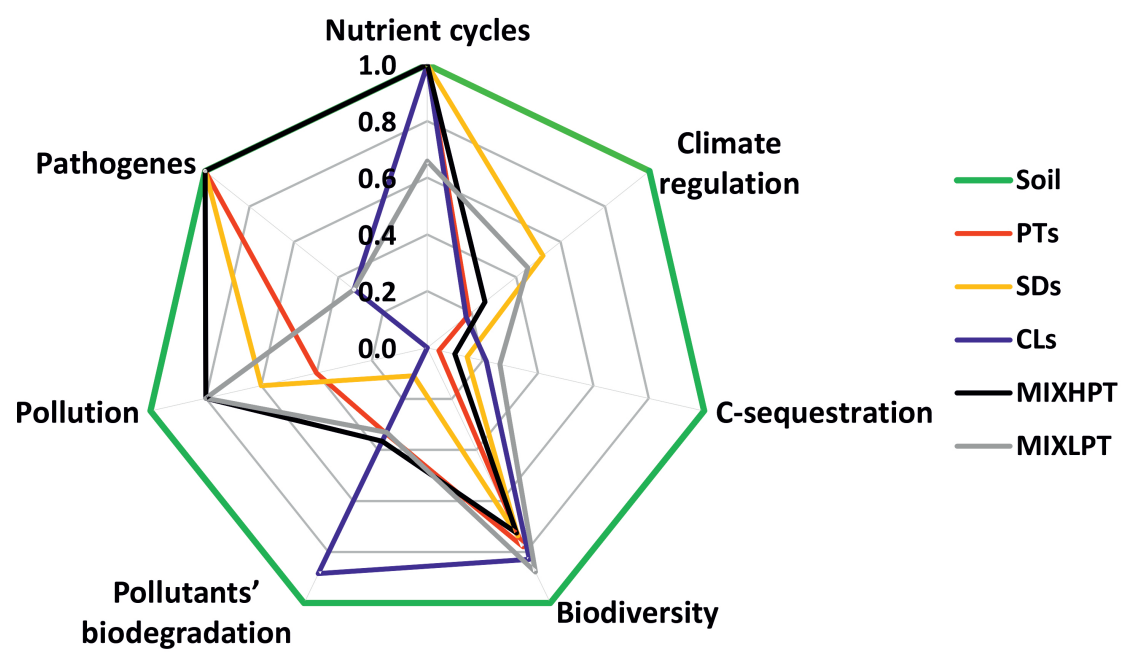

Figure 7. Estimation of ecosystem services ( 1 is the highest) and disservices ( 1 is the lowest) provided by different groups of materials: peats (PTs), sediments (SDs), cultural layers (CLs), high-peat $\left(\mathrm{MIX}_{\mathrm{HPT}}\right)$, and low-peat $\left(\mathrm{MIX}_{\mathrm{LPT}}\right)$ mixtures in relation to soil.

\section{Discussion}

\subsection{Advantages and Disadvantages of the Soil-like Materials from the Ecosystem Services' Perspective}

A comprehensive analysis of chemical and microbial properties of the materials projected into the ecosystem services' / disservices' assessment allowed ranking their quality and applicability for Technosols' construction. A high rank of the sediments, which balanced most of the analyzed services, is one of the principal and unexpected research outcomes. So far, dredged sediments are frequently used in agriculture as amendments [56-58], but in urban greening and landscaping, preference is traditionally given to C-rich 'dark' materials, which are supposed to be more fertile [5]. In fact, dredged sediments combined with biosolids can considerably improve soil fertility and support plant growth as it was shown for Chicago [9]. Technosols constructed from water treatment station sediments 
and composts had high nutrient contents and showed a positive dynamics in formation of stable aggregates $[18,59]$. Mixing sediments with clay loam, sand, and peat in volumetric proportions 25/30/40/5 or 15/40/40/5 at the pilot project in Moscow allowed constructing Technosols, whose quality satisfied governmental ecological and health standards [59-61]. These examples confirm our conclusion that non-polluted sediments could make a good alternative for the excavated natural and arable soils in composed mixtures for Technosols' construction, especially in the regions where the sedimentation in the water reservoirs is an important problem and dredging activities are needed.

In comparison to sediments, a considerably lower capacity to provide climate regulation and C-sequestration services was shown for the valley peat and high-peat mixtures, which so far dominate the greening markets of Moscow [5,34] and many other cities in Europe [62]. Although the nutrient content in peat materials is high, their vast implementation for Technosols' construction can result in a dramatic increase in $\mathrm{CO}_{2}$ release to the atmosphere due to intensive mineralization of easily mineralizable organic matter $[63,64]$, which can be even more facilitated by urban heat island effect [65]. We do not appeal for a complete ban for peat implementation in Technosols' construction; however, the proportions shall be thoroughly verified. Based on the research outcomes, a minor addition $(\leq 30 \%)$ of peat in the mixture composition didn't have a negative impact on the climate regulation and $\mathrm{C}$-sequestration services and contributed to microbial functional diversity, which is in agreement with the previous studies [66].

Urban cultural layers were probably the most "exotic" group of materials we tested, due to specific genesis, properties, and limited implementation for greening and landscaping needs. Cultural layers include various deposits that reflected the anthropogenic activity in the past: wood chips, wastes, excavated bedrock, bricks, and gardening traces [67]. We are not aware of a widely spread practical application of the cultural layers in soil engineering; however, the nutrients' richness could make them attractive for this purpose. Urban cultural layers showed high microbial activity and C-availability indicated by a high potential to accumulate $C$ in microbial cells. As a result, the high capacity in pollutants' biodegradation, C-sequestration, and functional biodiversity was also observed. However, the intensive mineralization of organic matter increases the risks of $\mathrm{CO}_{2}$ emission and depletes the climate regulation service. Presence of pathogens (Aspergillus niger and Verticillium genera) and pollution by PTE (copper, zinc, lead), likely inherited from the historical land-use [35] are the principal disservices of cultural layer, which limit their application for Technosols' construction and urban greening.

\subsection{Microbial Properties of the Materials in Relation to Nutrients and PTE Contents}

Chemical and microbial properties in the studied materials were interrelated, and therefore, the variation in microbial indices and the values of corresponding ecosystem services were partly explained by nutrients' and PTE contents. Commonly, soil C and N contents stimulate microbial biomass growth [68,69]; however, in our study, a positive correlation between $\mathrm{C}$ and $\mathrm{N}$ contents and $q \mathrm{CO}_{2}$ was shown. Apparently, the energy costs for microorganisms to maintain their biomass under intensive input of $\mathrm{C}$ and $\mathrm{N}$ are too high. There is a threshold level of saturation, above which an additional input of organic matter doesn't stimulate microbial activity [70]. Apparently, in peats, cultural layers and high-peat mixtures this threshold was exceeded. This outcome doubts existing municipal regulations, which allow or even recommend the high content of organic matter in the materials used for soil construction. For instance, the permissible content of organic matter in materials used for landscaping in Moscow range from 10 to 25\% [60], which is completely unsustainable and can result in intensive $\mathrm{CO}_{2}$ emission.

Soil microbial properties are quite sensitive to pollution by PTE. However, in our study, such a negative effect was not evident, that is likely due to relatively low concentrations of the pollutants (for most of the materials, their contents were below health thresholds, Table 3). Moreover, based on the correlation analysis, MR was positively related to $\mathrm{Cd}$ and $\mathrm{Zn}$ contents. This unexpected outcome is likely explained by the specific properties of the 
cultural layers, where considerable contents of heave metals coincide with a very high $\mathrm{C}$ and $\mathrm{N}$ contents, and correspondingly, which a high microbial activity.

\subsection{Perspectives of Microbial Indicators for the Materials Quality Control}

Existing material quality standards often ignore the fundamental view on soil quality and ecosystem services [71,72]. For instance, Moscow government regulates the permissible values of organic matter, $\mathrm{pH}$, nutrients, as well as pollutants' content, pathogens, and weed seeds in the soil-like materials used for Technosols' construction and urban greening [60]. City of Evans municipality (Colorado, CO, USA) regulates $\mathrm{pH}$, nitrogen, phosphorus, organic matter contents, bulk density, texture, moisture, and soluble salt concentration in the amendments used in landscaping [73]. The British standard for topsoil cut and translocated in building construction considers texture, nitrogen, phosphorus, potassium, organic matter contents, and a wide range of pollutants for quality control [74]. None of these and other reviewed regulations consider microbial properties as an important criteria of urban soil quality. Today, even a shortlist of microbial indicators within the standardized protocols includes microbial (basal) respiration [41], microbial biomass [75], enzymes activity [76], nitrogen mineralization, and nitrification in soils [77]. Partly, implementation of these microbial indicators in urban soils' assessment is constrained by high temporal dynamics, especially during the first years after Technosols' construction $[78,79]$. From the other perspective, monitoring dynamics of these indicators can reflect the evolution and pedogenesis processes in the constructed soils. For instance, a positive dynamics of microbial biomass carbon in Technosols constructed from the mining wastes to remediate an industrial barren indicated their effectiveness for the ecosystem restoration [11]. Assessing microbial properties of soil-like materials could be a promising tool to project functions and ecosystem services of the constructed Technosols' and therefore shall not be ignored in urban landscaping, planning, and management.

\section{Conclusions}

An artificial origin of the constructed Technosols gives a unique opportunity to project their functions and ecosystem services based on selecting soil-like materials with particular chemical and microbial properties. Assessment of the materials used for Technosols' construction in Moscow showed the highest performance for the sediments, which so far are almost completely ignored in urban greening. Regarding nutrient contents and balanced microbial functioning, they can be recommended as a promising replacement of native soils in organo-mineral mixtures used in soil constructions. Much lower ranks were given to peats due to very high risks of $\mathrm{CO}_{2}$ emissions. Their implementation in Technosols constructions shall be limited to minor $(\leq 30 \%)$ amendments to mixtures composed from the sediments or native soil. Cultural layers were exposed to high biological (pathogens) and chemical (PTE) pollution, which was considered an ecosystem disservice. Therefore, they shall not be recommended for urban greening and landscaping. Although the research outcomes and recommendations are based on the analysis obtained for Moscow megapolis, they are applicable for many other world cities since most of the investigated materials (e.g., peat, sediments, and organo-mineral mixtures) are universal and widely spread. Our study showed the efficiency of microbial properties for testing the quality of materials and their potential to contribute to the ecosystem services provided by constructed Technosols already at the planning stage. Assessment of microbial functional capacity can be an important factor for developing recommendations on materials and technologies to enhance ecosystem services of urban soil constructions and support urban sustainable development. 
Author Contributions: Conceptualization, K.I., E.L., S.M. and V.V.; methodology, K.I., V.V., N.A., F.K.; software, K.I.; validation, A.D., S.S., I.V., A.S. and S.M.; formal analysis, K.I., I.V.; investigation, K.I., E.L., S.D.; resources, V.V., E.D.; data curation, K.I., E.L. and V.V.; writing-original draft preparation, K.I. and. V.V.; writing-review and editing, V.V., K.I., N.A., S.D.; visualization, K.I.; supervision, V.V., K.I., S.M.; project administration, E.D.; funding acquisition, V.V., K.I. All authors have read and agreed to the published version of the manuscript.

Funding: Functions of soil mixtures and their components were studied as a part of the Russian Science Foundation No 17-77-20046. Field investigations, sampling, and microbial analysis were supported by RFBR project No 19-34-90133. Data synthesis and paper preparation were supported by the RUDN University Strategic Leadership Program.

Institutional Review Board Statement: Not applicable.

Informed Consent Statement: Not applicable.

Data Availability Statement: The data presented in the study are available upon request from the corresponding authors.

Conflicts of Interest: The authors declare no conflict of interest.

\section{References}

1. Grimm, N.B.; Faeth, S.H.; Golubiewski, N.E.; Redman, C.L.; Wu, J.; Bai, X.; Briggs, J.M. Global change and the ecology of cities. Science 2008, 319, 756-760. [CrossRef] [PubMed]

2. $\quad$ Pickett, S.T.A.; Cadenasso, M.L.; Grove, J.M.; Boone, C.G.; Groffman, P.M.; Irwin, E.; Kaushal, S.S.; Marshall, V.; McGrath, B.P.; Nilon, C.H.; et al. Urban ecological systems: Scientific foundations and a decade of progress. J. Environ. Manag. 2011, 92, 331-362. [CrossRef] [PubMed]

3. Gómez-Baggethun, E.; Barton, D.N. Classifying and valuing ecosystem services for urban planning. Ecol. Econ. 2013, 86, 235-245. [CrossRef]

4. Lehmann, A.; Stahr, K. Nature and significance of anthropogenic urban soils. J. Soils Sediments 2007, 7, 247-260. [CrossRef]

5. Brianskaia, I.P.; Vasenev, V.I.; Brykova, R.A.; Markelova, V.N.; Ushakova, N.V.; Gosse, D.D.; Gavrilenko, E.V.; Blagodatskaya, E.V. Analysis of volume and properties of imported soils for prediction of carbon stocks in soil constructions in the Moscow metropolis. Eurasian Soil Sci. 2020, 53, 1809-1817. [CrossRef]

6. Deeb, M.; Groffman, P.M.; Blouin, M.; Egendorf, S.P.; Vergnes, A.; Vasenev, V.; Cao, D.L.; Walsh, D.; Morin, T.; Séré, G. Using constructed soils for green infrastructure-Challenges and limitations. Soil 2020, 6, 413-434. [CrossRef]

7. Fabbri, D.; Pizzol, R.; Calza, P.; Malandrino, M.; Gaggero, E.; Padoan, E.; Ajmone-Marsan, F. Constructed technosols: A strategy toward a circular economy. Appl. Sci. (Switzerland) 2021, 11, 3432. [CrossRef]

8. Smagin, A.V.; Sadovnikova, N.B. Creation of soil-like constructions. Eurasian Soil Sci. 2015, 48, 981-990. [CrossRef]

9. Brose, D.A.; Hundal, L.S.; Oladeji, O.O.; Kumar, K.; Granato, T.C.; Cox, A.; Abedin, Z. Greening a steel mill slag brownfield with biosolids and sediments: A case study. J. Environ. Qual. 2016, 45, 53-61. [CrossRef] [PubMed]

10. Vasenev, V.I.; Smagin, A.V.; Ananyeva, N.D.; Ivashchenko, K.V.; Gavrilenko, E.G.; Prokofeva, T.V.; Patlseva, A.; Stoorvogel, J.J.; Gosse, D.D.; Valentini, R. Urban soil's functions: Monitoring, assessment, and management. In Adaptive Soil Management: From Theory to Practices; Rakshit, A., Abhilash, P., Singh, H., Ghosh, S., Eds.; Springer: Singapore, 2017; pp. 359-409.

11. Slukovskaya, M.V.; Vasenev, V.I.; Ivashchenko, K.V.; Morev, D.V.; Drogobuzhskaya, S.V.; Ivanova, L.A.; Kremenetskaya, I.P. Technosols on mining wastes in the subarctic: Efficiency of remediation under Cu-Ni atmospheric pollution. Int. Soil Water Conserv. Res. 2019, 7, 297-307. [CrossRef]

12. Séré, G.; Schwartz, C.; Ouvrard, S.; Sauvage, C.; Renat, J.C.; Morel, J.L. Soil construction: A step for ecological reclamation of derelict lands. J. Soils Sediments 2008, 8, 130-136. [CrossRef]

13. Burghardt, W.; Morel, J.L.; Zhang, G.L. Development of the soil research about urban, industrial, traffic, mining and military areas (SUITMA). Soil Sci. Plant Nutr. 2015, 61, 3-21. [CrossRef]

14. Kumar, K.; Hundal, L.S. Soil in the city: Sustainably improving urban soils. J. Environ. Qual. 2016, 45, 2-8. [CrossRef] [PubMed]

15. Vidal-Beaudet, L.; Schwartz, C.; Séré, G. Using Wastes for Fertile Urban Soil Construction-The French Research Project SITERRE. In Soils within Cities; Levin, M.J., Kim, K.-H.J., Morel, J.L., Burghardt, W., Charzynski, P., Shaw, R.K., IUSS Working Group SUITMA, Eds.; Schweizerbart Science Publishers: Stuttgart, Germany, 2017; pp. 159-168.

16. Municipality of Parma. Municipal Regulation of Public and Private Green Areas; Municipality of Parma: Parma, Italy, 2016. (In Italian)

17. Malenkovska Todorova, M.; Donceva, R.; Bunevska, J. Road Regulation and Functional Classification of the Urban Streets of Rome Capital. Transp. Probl. 2009, 4, 97-104.

18. Fourvel, G.; Vidal-Beaudet, L.; le Bocq, A.; Brochier, V.; Théry, F.; Landry, D.; Kumarasamy, T.; Cannavo, P. Early structural stability of fine dam sediment in soil construction. J. Soils Sediments 2018, 18, 2647-2663. [CrossRef]

19. Morel, J.L.; Chenu, C.; Lorenz, K. Ecosystem services provided by soils of urban, industrial, traffic, mining, and military areas (SUITMAs). J. Soils Sediments 2015, 15, 1659-1666. [CrossRef] 
20. Vasenev, V.I.; van Oudenhoven, A.P.E.; Romzaykina, O.N.; Hajiaghaeva, R.A. The ecological functions and ecosystem services of urban and technogenic soils: From theory to practice (a review). Eurasian Soil Sci. 2018, 51, 1119-1132. [CrossRef]

21. Saccá, M.L.; Caracciolo, A.B.; di Lenola, M.; Grenni, P. Ecosystem services provided by soil microorganisms. In Soil Biological Communities and Ecosystem Resilience; Springer: Cham, Switzerland, 2017. [CrossRef]

22. Frey, S.D.; Drijber, R.; Smith, H.; Melillo, J. Microbial biomass, functional capacity, and community structure after 12 years of soil warming. Soil Biol. Biochem. 2008, 40, 2904-2907. [CrossRef]

23. Diakhaté, S.; Gueye, M.; Chevallier, T.; Diallo, N.H.; Assigbetse, K.; Abadie, J.; Diouf, M.; Masse, D.; Sembène, M.; Ndour, Y.B.; et al. Soil microbial functional capacity and diversity in a millet-shrub intercropping system of semi-arid senegal. J. Arid. Environ. 2016, 129, 71-79. [CrossRef]

24. Kumaresan, D.; Cross, A.T.; Moreira-Grez, B.; Kariman, K.; Nevill, P.; Stevens, J.; Allcock, R.J.N.; O’Donnell, A.G.; DIxon, K.W.; Whiteley, A.S. Microbial functional capacity is preserved within engineered soil formulations used in mine site restoration. Sci. Rep. 2017, 7, 1-9. [CrossRef] [PubMed]

25. Joergensen, R.G.; Emmerling, C. Methods for evaluating human impact on soil microorganisms based on their activity, biomass, and diversity in agricultural soils. J. Plant Nutr. Soil Sci. 2006, 169, 295-309. [CrossRef]

26. Ritz, K.; Black, H.I.J.; Campbell, C.D.; Harris, J.A.; Wood, C. Selecting biological indicators for monitoring soils: A framework for balancing scientific and technical opinion to assist policy development. Ecol. Indic. 2009, 9, 1212-1221. [CrossRef]

27. Marinari, S.; Bonifacio, E.; Moscatelli, M.C.; Falsone, G.; Antisari, L.V.; Vianello, G. Soil development and microbial functional diversity: Proposal for a methodological approach. Geoderma 2013, 192, 437-445. [CrossRef]

28. Moscatelli, M.C.; Secondi, L.; Marabottini, R.; Papp, R.; Stazi, S.R.; Mania, E.; Marinari, S. Assessment of soil microbial functional diversity: Land use and soil properties affect CLPP-MicroResp and enzymes responses. Pedobiologia 2018, 66, 36-42. [CrossRef]

29. Escalas, A.; Hale, L.; Voordeckers, J.W.; Yang, Y.; Firestone, M.K.; Alvarez-Cohen, L.; Zhou, J. Microbial functional diversity: From concepts to applications. Ecol. Evol. 2019, 9, 12000-12016. [CrossRef] [PubMed]

30. Marfenina, O.E.; Makarova, N.V.; Ivanova, A.E. Opportunistic fungi in soils and surface air of a megalopolis (for the Tushino Region, Moscow). Microbiology 2011, 80, 870-876. [CrossRef]

31. Korneykova, M.V.; Myazin, V.A.; Fokina, N.V.; Chaporgina, A.A. Bioremediation of soil of the kola peninsula (Murmansk region) contaminated with diesel fuel. Geogr. Environ. Sustain. 2021, 14, 171-176. [CrossRef]

32. Stroganova, M.N.; Myagkova, A.D.; Prokof'eva, T.V. The role of soils in urban ecosystems. Eurasian Soil Sci. 1997, $30,82-86$.

33. Prokofyeva, T.V.; Martynenko, I.A.; Ivannikov, F.A. Classification of Moscow soils and parent materials and its possible inclusion in the classification system of Russian soils. Eurasian Soil Sci. 2011, 44, 561-571. [CrossRef]

34. Prokhorov, I.S.; Karev, S.Y. Particularities of artificial soil-ground production for landscape and shade gardening. Agrochem. Her. 2012, 3, 21-25. (In Russian)

35. Alexandrovskiy, A.L.; Dolgikh, A.V.; Alexandrovskaya, E.I. Pedogenetic features of habitation deposits in ancient towns of european russia and their alteration under different natural conditions. Bol. De La Soc. Geol. Mex. 2012, 64, 71-77. [CrossRef]

36. Vasenev, V.I.; Stoorvogel, J.J.; Dolgikh, A.V.; Ananyeva, N.D.; Ivashchenko, K.V. Changes in soil organic carbon stocks by urbanization. In Advance in Soil Science "Urban Soils"; Lal, R., Stewart, B.A., Eds.; CRC Press Taylor and Francis Group: New York, NY, USA, 2017; pp. 61-93.

37. Anderson, J.P.E.; Domsch, K.H. A physiological method for the quantitative measurement of microbial biomass in soils. Soil Biol. Biochem. 1978, 10, 215-221. [CrossRef]

38. Ananyeva, N.D.; Susyan, E.A.; Chernova, O.V.; Wirth, S. Microbial respiration activities of soils from different climatic regions of European Russia. Eur. J. Soil Biol. 2008, 44, 147-157. [CrossRef]

39. Creamer, R.E.; Schulte, R.P.O.; Stone, D.; Gal, A.; Krogh, P.H.; lo Papa, G.; Murray, P.J.; Pérès, G.; Foerster, B.; Rutgers, M.; et al. Measuring basal soil respiration across europe: Do incubation temperature and incubation period matter? Ecol. Indic. 2014, 36, 409-418. [CrossRef]

40. Kroetsch, D.; Wang, C. Soil Sampling and Methods of Analysis, 2nd ed.; Carter, M.R., Gregorich, E.G., Eds.; CRC Press: Boca Raton, FL, USA, 2007. [CrossRef]

41. ISO. Soil quality-laboratory methods for determination of microbial soil respiration; International Organization for Standardization: Geneva, Switzerland, 2002.

42. Dilly, O. Microbial energetics in soils. In Microorganisms in Soils: Roles in Genesis and Functions; Springer: Berlin, Heidelberg, 2005. [CrossRef]

43. Campbell, C.D.; Chapman, S.J.; Cameron, C.M.; Davidson, M.S.; Potts, J.M. A rapid microtiter plate method to measure carbon dioxide evolved from carbon substrate amendments so as to determine the physiological profiles of soil microbial communities by using whole soil. Appl. Environ. Microbiol. 2003, 69, 3593-3599. [CrossRef] [PubMed]

44. Shannon, C.; Weaver, W. The mathematical theory of comumunication; The University of Illinois Press: Champaign, IL, USA, 1964; 131p.

45. Davet, P.; Rouxel, F. Detection and Isolation of Soil Fungi; Science Publishers: Plymouth, UK, 2000.

46. Acea, M.J.; Carballas, T. Changes in physiological groups of microorganisms in soil following wildfire. FEMS Microbiol. Ecol. 1996, 20, 33-39. [CrossRef]

47. Marfenina, O.E.; Danilogorskaya, A.A. Effect of elevated temperatures on composition and diversity of microfungal communities in natural and urban boreal soils, with emphasis on potentially pathogenic species. Pedobiologia 2017, 60, 11-19. [CrossRef]

48. Seifert, K.A. Compendium of soil fungi-by Domsch, K.H.; Gams, W.; Anderson, T.H. Eur. J. Soil Sci. 2008, 59, 1007. [CrossRef] 
49. De Hoog, G.S.; Guarro, J.; Gené, J.; Ahmed, S.A.; Al-Hatmi, A.M.S.; Figueras, M.J.; Vitale, R.G. Atlas of Clinical Fungi, 4th ed.; Centraalbureau voor Schimmelcultures: Utrecht, The Netherlands, 2019.

50. Thiele-Bruhn, S.; Schloter, M.; Wilke, B.M.; Beaudette, L.A.; Martin-Laurent, F.; Cheviron, N.; Mougin, C.; Römbke, J. Identification of new microbial functional standards for soil quality assessment. SOIL 2020, 6, 17-34. [CrossRef]

51. Legendre, P.; Gallagher, E.D. Ecologically meaningful transformations for ordination of species data. Oecologia 2001, 129, 271-280. [CrossRef]

52. TeamCore, R.C. Language and Environment for Statistical Computing: R Foundation for Statistical Computing; The R Development Core Team: Vienna, Austria, 2018.

53. Wickham, H. Ggplot2 Elegant Graphics for Data Analysis (Use R!); Springer: New York, NY, USA, 2016.

54. Vasenev, V.I.; Stoorvogel, J.J.; Vasenev, I.I. Urban soil organic carbon and its spatial heterogeneity in comparison with natural and agricultural areas in the Moscow region. Catena 2013, 107, 96-102. [CrossRef]

55. Ivashchenko, K.; Ananyeva, N.; Vasenev, V.; Sushko, S.; Seleznyova, A.; Kudeyarov, V. Microbial C-availability and organic matter decomposition in urban soils of megapolis depend on functional zoning. Soil Environ. 2019, 38, 31-41. [CrossRef]

56. Darmody, R.G.; Marlin, J.C.; Talbott, J.; Green, R.A.; Brewer, E.F.; Stohr, C. Dredged Illinois river sediments: Plant growth and metal uptake. J. Environ. Qual. 2004, 33, 458-464. [CrossRef] [PubMed]

57. Vasbieva, M.T.; Kosolapova, A.I. Changes in fertility parameters and contents of heavy metals of soddy-podzolic soils upon the long-term application of sewage sludge. Eurasian Soil Sci. 2015, 48, 518-523. [CrossRef]

58. Plekhanova, I.O. Self-purification of agrosoddy-podzolic sandy loamy soils fertilized with sewage sludge. Eurasian Soil Sci. 2017, 50, 491-497. [CrossRef]

59. Shchegolkova, N.M.; Smagin, A.V.; Rybka, K.Y. Methodological aspects of soil engineering: Agrophysical properties (in Russian). Voda Khimiya Ekol. 2013, 7, 9-17.

60. HS-514-11 Moscow Government Document Regulates Quality of the Materials Applied for Greening in Moscow. 2019.

61. Khrenov, K.E.; Kozlov, M.N.; Shchegolkova, N.M.; Vanyushina, A.Y.; Grachev, V.A. Properties investigation of the created soils made from sediments of water treatment station (in Russian). Water Supply Sanit. Tech. 2011, 10, $20-25$.

62. Kitir, N.; Yildirim, E.; Şahin, Ü.; Turan, M.; Ekinci, M.; Ors, S.; Kul, R.; Ünlü, H.; Ünlü, H. Peat use in horticulture. In Peat; IntechOpen: London, UK, 2018. [CrossRef]

63. Shchepeleva, A.S.; Vasenev, V.I.; Mazirov, I.M.; Vasenev, I.I.; Prokhorov, I.S.; Gosse, D.D. Changes of soil organic carbon stocks and $\mathrm{CO}_{2}$ emissions at the early stages of urban turf grasses' development. Urban Ecosyst. 2017, 20, 309-321. [CrossRef]

64. Smagin, A.V.; Sadovnikova, N.B.; Vasenev, V.I.; Smagina, M.V. Biodegradation of some organic materials in soils and soil constructions: Experiments, modeling and prevention. Materials 2018, 11, 1889. [CrossRef] [PubMed]

65. Vasenev, V.; Varentsov, M.; Konstantinov, P.; Romzaykina, O.; Kanareykina, I.; Dvornikov, Y.; Manukyan, V. Projecting urban heat island effect on the spatial-temporal variation of microbial respiration in urban soils of moscow megalopolis. Sci. Total. Environ. 2021, 786, 147457. [CrossRef]

66. Kelly, J.J.; Favila, E.; Hundal, L.S.; Marlin, J.C. Assessment of soil microbial communities in surface applied mixtures of Illinois river sediments and biosolids. Appl. Soil Ecol. 2007, 36, 176-183. [CrossRef]

67. Alexandrovskaya, E.I.; Alexandrovskiy, A.L. History of the cultural layer in moscow and accumulation of anthropogenic substances in it. Catena 2000, 41, 249-259. [CrossRef]

68. Ivashchenko, K.V.; Ananyeva, N.D.; Vasenev, V.I.; Kudeyarov, V.N.; Valentini, R. Biomass and respiration activity of soil microorganisms in anthropogenically transformed ecosystems (Moscow region). Eurasian Soil Sci. 2014, 47, 892-903. [CrossRef]

69. Ovsepyan, L.; Kurganova, I.; de Gerenyu, V.L.; Kuzyakov, Y. Recovery of organic matter and microbial biomass after abandonment of degraded agricultural soils: The influence of climate. Land Degrad. Dev. 2019, 30, 1861-1874. [CrossRef]

70. Shahbaz, M.; Kuzyakov, Y.; Sanaullah, M.; Heitkamp, F.; Zelenev, V.; Kumar, A.; Blagodatskaya, E. Microbial decomposition of soil organic matter is mediated by quality and quantity of crop residues: Mechanisms and thresholds. Biol. Fertil. Soils 2017, 53, 287-301. [CrossRef]

71. Karlen, D.L.; Mausbach, M.J.; Doran, J.W.; Cline, R.G.; Harris, R.F.; Schuman, G.E. Soil quality: A concept, definition, and framework for evaluation (a guest editorial). Soil Sci. Soc. Am. J. 1997, 61, 4-10. [CrossRef]

72. Doran, J.W.; Zeiss, M.R. Soil health and sustainability: Managing the biotic component of soil quality. Appl. Soil Ecol. 2000, 15, 3-11. [CrossRef]

73. Aqua Engineering, Inc. City of Evans Standard: Lawn and Grass Specification Standard-02930; Aqua Engineering, Inc.: City of Evans, CO, USA, 2000.

74. British Standards Institution. BS 3882 Specification for Topsoil; British Standards Institution: London, UK, 2015.

75. ISO. ISO 14240-1 Soil Quality—Determination of Soil Microbial Biomass_Part 1: Substrate-Induced Respiration Method; International Organization for Standardization: Geneva, Switzerland, 1997.

76. ISO. ISO/TS 22939 (2019): Soil Quality-Measurement of Enzyme Activity Patterns in Soil Samples Using Fluorogenic Substrates in Micro-Well Plates; International Organization for Standardization: Geneva, Switzerland, 2019. 
77. ISO. ISO 14238 Soil Quality_Biological Methods_Determination of Nitrogen Mineralization and Nitrification in Soils and the Influence of Chemicals on These Processes; International Organization for Standardization: Geneva, Switzerland, 2012.

78. Hafeez, F.; Martin-Laurent, F.; Béguet, J.; Bru, D.; Cortet, J.; Schwartz, C.; Morel, J.L.; Philippot, L. Taxonomic and functional characterization of microbial communities in technosols constructed for remediation of a contaminated industrial wasteland. $J$. Soils Sediments 2012, 12, 1396-1406. [CrossRef]

79. Vidal-Beaudet, L.; Galopin, G.; Grosbellet, C. Effect of organic amendment for the construction of favourable urban soils for tree growth. Eur. J. Hortic. Sci. 2018, 83, 173-186. [CrossRef] 